\title{
Comprehension of climatic and occupational heat stress amongst agricultural advisers and workers in Slovenia
}

\author{
Tjaša POGAČAR ${ }^{1}$, Zalika ČREPINŠEK $^{2}$, Lučka KAJFEŽ BOGATAJ ${ }^{3}$, Lars NYBO ${ }^{4}$
}

Received July 17, 2017; accepted December 12, 2017.

Delo je prispelo 17. julija 2017, sprejeto 12. decembra 2017.

\begin{abstract}
Climate changes and the associated higher frequency of heat waves in Middle-European countries will aggravate occupational heat stress experienced by Slovenian workers. Appropriate behavioral adaptations are important coping strategies and it is pertinent to establish if knowledge among advisers and workers is sufficient and identify the symptoms experienced by workers. Therefore a survey including 230 farmers and 86 agricultural advisers was completed. Thermal comfort ranged from hot to extremely hot for $85 \pm 5 \%$ of farmers working outside and heat stress had a negative impact on well-being $(74 \pm 6 \%)$, productivity $(68 \pm 6 \%)$ and concentration $(34 \pm 6 \%)$. Reported symptoms were excessive sweating $(84 \pm 5 \%)$, thirst $(81 \pm 5 \%)$, and tiredness $(59 \pm$ $6 \%)$. Women had a higher prevalence of headache $(64 \pm$ $10 \%)$ compared to males $(47 \pm 8 \%)$, higher frequency of fatigue $(69 \pm 10$ vs $56 \pm 8 \%)$, and incidents with nausea or vomiting ( $19 \pm 8$ vs $9 \pm 5 \%) .81 \pm 4 \%$ of the responders reported that more time is required to complete tasks when the weather is hot. Nevertheless, $61 \pm 6 \%$ of farmers have never been informed of the impacts of heat stress and $29 \pm 10 \%$ of the agricultural advisers does not include this information in their guidance. This emphasizes the need for increased information and implementation of feasible solutions to mitigate the negative impact of heat stress on workers in the agricultural sector.
\end{abstract}

Key words: heat stress; labor; farmers; agricultural advisers; health; well-being

\section{IZVLEČEK}

POZNAVANJE VROČINSKEGA STRESA NA
DELOVNEM MESTU MED KMETIJSKIMI
SVETOVALCI IN DELAVCI V SLOVENIJI

V Sloveniji temperatura zraka narašča bolj kot v Evropi, zato je pomembno oceniti vplive vročinskega stresa na delovne razmere, sploh pri zunanjih delavcih, kot so kmetje. Raziskava je bila izvedena med 230 kmeti in 86 kmetijskimi svetovalci. Toplotno udobje je že zdaj neprimerno (vroče, prevroče ali zelo prevroče) za $85 \pm 5 \%$ kmetov, ko delajo zunaj, pri čemer vročinski stres vpliva na počutje (74 $\pm 6 \%$ ), storilnost (68 \pm $6 \%$ ) in zbranost $(34 \pm 6 \%)$ kmetov. Osnovni zaznani simptomi vročinskega stresa so povečano potenje $(84 \pm 5 \%)$, žeja $(81 \pm 5 \%)$ in utrujenost $(59 \pm 6 \%)$. Ženske statistično značilno v večjem deležu poročajo o glavobolih $(64 \pm 10 \%$ žensk in $47 \pm 8 \%$ moških), izčrpanosti $(69 \pm 10$ in $56 \pm 8 \%)$ in slabosti oz. bruhanju $(19 \pm 8$ in $9 \pm 5 \%)$. Kmetje in svetovalci skupno $\mathrm{v}$ več kot $80 \%(81 \pm 4 \%)$ navajajo, da kmetje v času vročinskih valov za isto delo potrebujejo več časa. Kljub temu $61 \pm 6 \%$ kmetov še nikoli ni bilo obveščenih o vplivih vročinskega stresa, $29 \pm 10 \%$ svetovalcev pa še nikoli ni svetovalo o tem. Zelo jasno se kaže potreba po pripravi uporabnih, ne preveč splošnih smernic in možnih rešitev za zmanjšanje negativnega vpliva vročinskega stresa na kmete.

Ključne besede: vročinski stres; delovno mesto; kmetje; kmetijski svetovalci; zdravje, počutje

\footnotetext{
1 Ph.D., University of Ljubljana, Biotechnical Faculty, Agronomy Department, Jamnikarjeva ulica 101, SI-1111 Ljubljana, Slovenia, tjasa.pogacar@bf.uni-lj.si

2 doc. Ph.D., University of Ljubljana, Biotechnical Faculty, Agronomy Department, Jamnikarjeva ulica 101, SI-1111 Ljubljana, Slovenia

3 prof. Ph.D., University of Ljubljana, Biotechnical Faculty, Agronomy Department, Jamnikarjeva ulica 101, SI-1111 Ljubljana, Slovenia

4 prof. Ph.D., University of Copenhagen, Department of Nutrition, Exercise and Sports, August Krogh Bygningen, Universitetsparken 13, 2100 København, Denmark
} 


\section{INTRODUCTION}

Occupational heat stress and the associated impact on workers productivity and health may vary across industries, but heat issues are pertinent in both outdoor and indoor industrial sectors and problems expected to aggravate with future climate changes (Spector and Sheffield, 2014). Excessive workplace heat is a wellknown occupational health and productivity problem with high body temperature or dehydration influencing heat exhaustion, heat stroke and in extreme cases with a mortal outcome (Hübler et al., 2008; Lumingu and Dessureault, 2009; Lucas et al., 2014; Li et al., 2016; UNDP, 2016; Venugopal et al., 2016; Xiang et al., 2016). Risks to occupational health and labor productivity are more pronounced if workers are engaged in heavy work performed outside or indoor conditions without possibility to cool the air (Nilsson and Kjellstrom, 2010; Zander et al., 2015; Zhang et al., 2016; UNDP, 2016).

Climate changes are expected to alter the future thermal conditions and for Slovenia it is forecasted that with a moderate greenhouse gas emission scenario (RCP4.5) an increase of annual average air temperature by $1^{\circ} \mathrm{C}$ in the period 2011-2040 regarding 1981-2010 and by another $1{ }^{\circ} \mathrm{C}$ in the period $2041-2070$ is expected (ARSO, 2016; Morabito et al., 2017). Direct productivity losses associated with occupational heat stress may become substantial (Ioannou et al., 2017; Nybo et al., 2017) and if risk factors and costs related to deal with at higher levels of warming are considered, it will have immense impact for workers and employers relying on outdoor or non-air conditioned work. Therefore, actions and more detailed research and analysis of this issue is urgently required (UNDP, 2016; Nybo et al., 2017). The impact of heat stress can be mitigated, but actions are mainly limited by affordability, infrastructure, working regime, energy availability etc. so the reduction of negative effects of excessive direct heat exposure on the health and productivity of working people can be very difficult (Nilsson and Kjellstrom, 2010).

According to UNDP (2016), more than hundred studies in the last decade have addressed the health risks and labor productivity loss experienced by workers in hot locations. Recently, Venugopal et al. (2016) investigated the thermal conditions of migrant workers in India, Zhang et al. (2016) studied heat stress effects among migrant and seasonal farmworkers in Colorado and Xiang et al. (2016) investigated outdoor workers ( $2 \%$ of them were farmers) in South Australia. Collectively, these studies indicate that although action plans are available for these counties, there are large knowledge gaps on effective methods to mitigate heat stress and address associated risk amongst the agricultural workers. Recently, Ioannou et al. (2017) applied time-motion analysis as a novel approach for evaluating the impact of environmental heat exposure on labor loss in agriculture workers in Greece and it is quite clear that heat is a pertinent problem for European workers already at current summer temperatures. But apart from that study there appears to be a marked gap in the knowledge of workplace heat on agricultural workers in Europe and it is unclear if knowledge amongst workers and advisers is sufficient.

Agricultural advisers are important for guiding farmers on daily issues, seasonal scheduling and prolonged strategic planning, but it appears that in relation to occupational heat stress, there is large prerequisite for updated knowledge and increased awareness on the impact of climate changes on the agricultural sector (Mase et al., 2015). Heat stress relies both on environmental and individual factors and it is of importance to understand how specific farmers and agricultural advisers perceive the heat risk on the workplace, as this information may be helpful for preparing or updating heat stress prevention strategies (Spector and Sheffield, 2014; Xiang et al., 2016). E.g. women appear to be more vulnerable to heat stress compared to age matched males (Flouris et al., 2017); however, gender is an underrepresented variable in the field of climate change or analyses of the impact of heat stress on health (Preet et al., 2010). But for scenario specific advises indeed of importance to make heat prevention resources more focused (Nilsson and Kjellstrom, 2010). Therefore, it is the aim of this paper to represent the current state of the perception of heat stress and knowledge on its impacts among agricultural advisers and farmers in Slovenia.

\section{MATERIALS AND METHODS}

The current survey used a comprehensive questionnaire based on Hothaps (The High Occupational Temperature, Health, and Productivity Suppression) Program (Kjellstrom et al., 2011) and was conducted among 86 agricultural advisers and 230 farmers (for
$32 \%$ with farming as the only financial source) in Slovenia. Gender groups were quite homogeneous $42 \%$ women among advisers and $38 \%$ among farmers. Age groups were of comparable sizes, except for a very big group of advisers from 51 to 60 years (54\%); 
whereas this age group included only $20 \%$ farmers. $8 \%$ advisers and $13 \%$ farmers were above 60 years and the group from 41 to 50 years represented $22 \%$ advisers and $26 \%$ farmers. The 31 to 40 year group included $15 \%$ advisers and $25 \%$ farmers, and the groups younger than 31 had $1 \%$ advisers and $16 \%$ farmers. Advisers and some farmers were well educated: $51 \%$ of the advisers with completed college $(27 \%$ for the farmers), university completed for $17 \%$ with $6 \%$ (4\% farmers) obtaining a master or doctoral degree. Primary school was the highest degree completed for $7 \%$ farmers, while $45 \%$ reported secondary school as their educational background. The major shares of advisers were from Pomurska $(27 \%)$, Savinjska $(23 \%)$ and Gorenjska $(20 \%)$ region; and the major share of farmers from Gorenjska (40\%), followed by Savinjska $(16 \%)$ and Zasavska $(15 \%)$ region. The main focus of farmers is livestock for meat $(30 \%)$ and milk $(22 \%)$, the next is crops production $(10 \%) .30 \%$ reported having some kind of chronic disease. Farmers reported that time expenditure for outside work was: up to onethird of total working hours for $22 \%, 39 \%$ reported between one to two-thirds and $39 \%$ more than twothirds of the weekly working hours.

The survey was conducted on-line in the period from September 2016 to April 2017. Results were analyzed using t-test and Chi-Square test in SPSS at $95 \%$ confidence level $(p<0.05)$.

\section{RESULTS AND DISCUSSION}

\subsection{Knowledge on heat waves and their impact}

Advisers (more than 80\%) and farmers (60\%) described heat wave as a short or long period (descriptions ranging from more than 2 and up to 14 days) with maximum daily air temperatures above $30^{\circ} \mathrm{C}$ or simply as temperatures high above average. Some descriptions/definitions of heat wave were based on perceptions: aggravated working conditions, unbearable conditions, decreased psychophysical and cognitive capabilities, hindering the growth of crops, productivity loss, impacts on animal reproduction, impacts on human and animal health, enhanced stress, inevitably, worrying conditions.

Both advisers and farmers were asked to assess effects of heat waves on five economic sectors from negligible to very high (Table 1$)$. The majority (62\% advisers,
$44 \%$ farmers) assessed it as very high on the agriculture sector, and the highest share of farmers also on construction sector $(35 \%)$. The highest shares of advisers saw the effect of heat waves on construction and manufacturing sector as moderate (33 and $37 \%$, respectively), and on tourism and transport as minor ( 35 and $28 \%$, respectively). For the highest share of farmers is the effect on tourism, transport and manufacturing only minor $(34,33$, and $37 \%$, respectively). For all sectors and both, advisers and farmers, there are statistically significant differences among five possible answers - from negligible effect to very high. Less than $18 \%$ of the survey participant considered heat wave as negligible in any sector. Differences between effect assessments of advisers and farmers are statistically significant only for the construction sector.

Table 1: Advisers' (A) and farmers' (F) assessment (and standard deviation) of effects of heat waves on five economic sectors with p-values for the difference between effect assessment of advisers and farmers

Preglednica 1: Vpliv vročinskih valov na pet gospodarskih sektorjev, kot so ga ocenili kmetijski svetovalci (A) in kmetje (F) (povprečna ocena in standardni odklon), ter p-vrednosti za razlike med ocenami svetovalcev in kmetov

\begin{tabular}{|c|c|c|c|c|c|c|c|c|c|c|c|}
\hline \multirow[t]{2}{*}{ Sector/Effect } & \multicolumn{2}{|c|}{ Negligible (\%) } & \multicolumn{2}{|l|}{$\begin{array}{l}\text { Minor } \\
(\%)\end{array}$} & \multicolumn{2}{|c|}{ Moderate (\%) } & \multicolumn{2}{|l|}{$\begin{array}{l}\text { High } \\
(\%)\end{array}$} & \multicolumn{2}{|c|}{$\begin{array}{l}\text { Very high } \\
(\%)\end{array}$} & \multirow{2}{*}{$\begin{array}{l}\text { Chi- } \\
\text { Square } \\
p \text {-value }\end{array}$} \\
\hline & $\mathrm{A}$ & $\mathrm{F}$ & $\mathrm{A}$ & $\mathrm{F}$ & $\mathrm{A}$ & $\mathrm{F}$ & A & $\mathrm{F}$ & A & $\mathrm{F}$ & \\
\hline Tourism & 8.1 & 15.2 & 34.9 & 33.9 & 26.7 & 23.5 & 25.6 & 22.6 & 4.7 & 4.8 & 0.58 \\
\hline $\mathrm{sd}$ & 2.9 & 2.4 & 5.1 & 3.1 & 4.8 & 2.8 & 4.7 & 2.8 & 2.3 & 1.4 & \\
\hline Agriculture & 2.3 & 2.2 & 1.2 & 3.5 & 12.8 & 17.4 & 22.1 & 33.5 & 61.6 & 43.5 & 0.06 \\
\hline $\mathrm{sd}$ & 1.6 & 1.0 & 1.2 & 1.2 & 3.6 & 2.5 & 4.5 & 3.1 & 5.2 & 3.3 & \\
\hline Transport & 10.5 & 13.5 & 28.3 & 32.6 & 22.1 & 30.0 & 25.6 & 21.7 & 9.3 & 6.5 & 0.51 \\
\hline $\mathrm{sd}$ & 3.3 & 2.2 & 4.9 & 3.1 & 4.5 & 3.0 & 4.7 & 2.7 & 3.1 & 1.6 & \\
\hline Manufacturing & 8.1 & 17.4 & 34.9 & 37.4 & 37.2 & 23.0 & 12.8 & 16.5 & 7.0 & 5.7 & 0.06 \\
\hline $\mathrm{sd}$ & 2.9 & 2.5 & 5.1 & 3.2 & 5.2 & 2.8 & 3.6 & 2.4 & 2.8 & 1.5 & \\
\hline Construction & 4.4 & 4.7 & 18.6 & 20.0 & 33.7 & 27.4 & 18.6 & 13.0 & 24.4 & 35.2 & 0.002 \\
\hline $\mathrm{sd}$ & 2.2 & 1.4 & 4.2 & 2.6 & 5.1 & 2.9 & 4.2 & 2.2 & 4.6 & 3.1 & \\
\hline
\end{tabular}




\subsection{Specific issues for the agricultural sector}

When asked about working conditions in agriculture, advisers responded that farmers are under the highest impact of a heat stress when they are working outside (in fields, grasslands, orchards, vineyards, forest), especially if they have manual work, and in barns which are not properly ventilated. Farmers confirmed this as the majority reported the highest impact of the heat stress during grass harvesting $(48 \%)$, field work $(20 \%)$, any manual work outside $(17 \%)$, or work in barns $(9 \%)$.
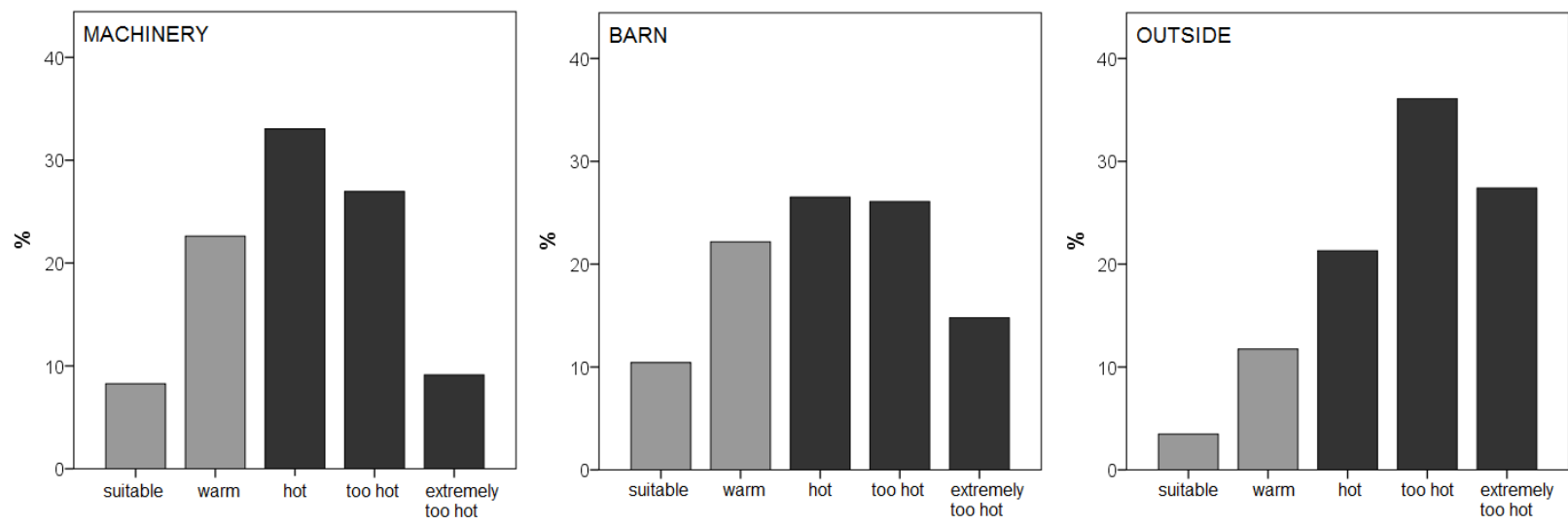

Figure 1: Farmers' assessment of thermal comfort (from suitable to extremely too hot conditions) when working with machinery (left), in the barn (middle) and outside (right)

Slika 1: Toplotno ugodje (od ustreznega do zelo prevročih razmer) pri delu s kmetijsko mehanizacijo (levo), v hlevu (na sredini) in zunaj (desno), kot ga ocenjujejo kmetje

Less than $10 \%$ of the farmers considered air temperatures during a heat wave as suitable for moderate to intense manual work; specifically $10 \%$ when working in a barn, $8 \%$ when working with machinery (e.g. tractor) and for only $3 \%$ when working outside (Figure 1). For these work categories it was reported extremely hot for 9,15 and $27 \%$ of farmers. Considering the categories 'hot', 'too hot' and 'extremely hot' gives the approximation of inappropriate working conditions during a heat wave and was reported for $69 \%$ of workers using machinery, $67 \%$ of workers in barns and $85 \%$ of workers outside. Thermal comfort assessment did not differ significantly across gender, age groups or reported chronical disease. However, thermal comfort in barns and outside was depending on working time spent outside.

\subsection{Perceived thermal discomfort and reported symptoms}

Farmers reported that heat stress influenced well-being (74\% farmers), productivity (68\%) and concentration (34\%) during heat waves (see Figure 2 left). This was not related to age, gender or working time spent outside. However, the impact on productivity was significantly related to reporting a chronical disease. Only $6 \%$ of farmers reported that a heat wave did not influence their work and a similar proportion of the advisers considered exposure to heat stress as no problem for farmers productivity or well-being. In contrast, $55 \%$ of the advisers consider that heat stress frequently causes problems, especially when a heat wave is prolonged or frequently occuring during the summer. $26 \%$ of the advisor consider heat stress as a minor problem, while $14 \%$ contemplate that heat waves are associated with major problems for the aggricultural worker (Figure 2 right). 

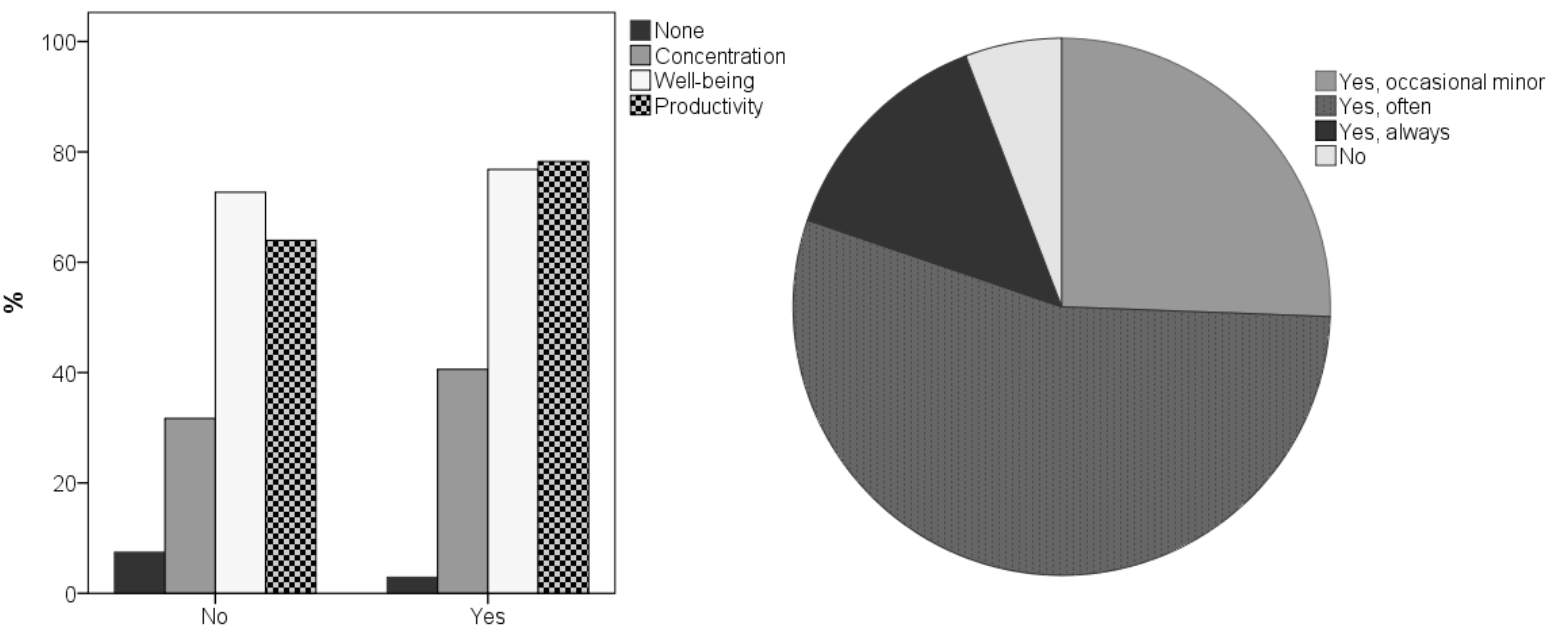

Figure 2: Farmers' assessment of heat waves' impacts on work related to reporting having a chronical disease (No/Yes; left panel) and advisers' assessment of problems that heat waves are causing to farmers (No problems; occasional minor problems; often, especially when the heat waves are longer or more frequent; always; right figure)

Slika 2: Vplivi vročinskih valov na delo, kot jih ocenjujejo kmetje glede na to ali imajo kakšno kronično bolezen (Yes) ali ne (No); levo, in ocena kmetijskih svetovalcev o težavah, ki se pojavijo pri delu kmetov v času vročinskih valov (od zgoraj navzdol: občasno se pojavijo manjše težave; pogosto se pojavijo težave, še posebej ob daljših in bolj pogostih vročinskih valovih; vedno se pojavijo težave; nikoli; desno)

With 3 out of 4 farmers reporting that heat waves impact their well-being, it is important to research further on, which symptoms they report in the summertime and what heat-induced health problems they experience during heat waves (Figure 3). The most common symptoms of heat stress are excessive sweating $(84 \%)$, thirst $(81 \%)$, and tiredness $(59 \%)$, followed by enhanced stress ( $25 \%)$, dizziness ( $24 \%)$, and confusion $(10 \%)$. There were significant differences among age groups in relation to excessive sweating and thirst, with more farmers under 40 years reporting problems on these issues compared to workers above 40 years. In regard to gender differences, there were more females experiencing tiredness and dizziness; the same goes for those with chronical diseases, who also perceive enhanced stress in higher percentages. Alike, heat-rashes, dehydration, heat syncope and urinogenital symptoms were self-reported health issues in the study in India among 442 outdoor workers (Venugopal et al., 2016). Affirmative response for any one of the heat-related symptoms such as excessive sweating or thirst, tiredness, cramps, headache, nausea/ vomiting, fainting, prickly heat or urinogenital issues was $96 \%$.
Heat-induced health problems may occur during heat waves if workers do not act in time after first symptoms or if they do not have an opportunity to reduce heat stress. There are statistically significant more men (20\%) reporting that they never had any kind of health problems than women $(8 \%)$. Women have significantly in higher share than men already experienced a headache (64 and $46 \%$, respectively), exhaustion (69 and $56 \%$, respectively), and nausea or vomiting (19 and $8 \%$, respectively). Fainting is also more common in female than in a male group (11 and $6 \%$, respectively), while it is the other way around for prickly heat $(8 \%$ women, $13 \%$ men), muscle cramps ( $2 \%$ women, $6 \%$ men) and heat cramps ( $0 \%$ women, $0.7 \%$ men). There have not yet been a heat stroke among respondents, however, 13 of them have already been hospitalized due to heat-induced problems. According to Xiang et al. (2016), had $37 \%$ of outside workers in Australia (2\% of them were farmers) experienced heat illnesses during hot days. The most common type reported was heat exhaustion $(61 \%)$, followed by heat rashes $(43 \%)$, heat stroke (26\%), and heat cramps (18\%). 

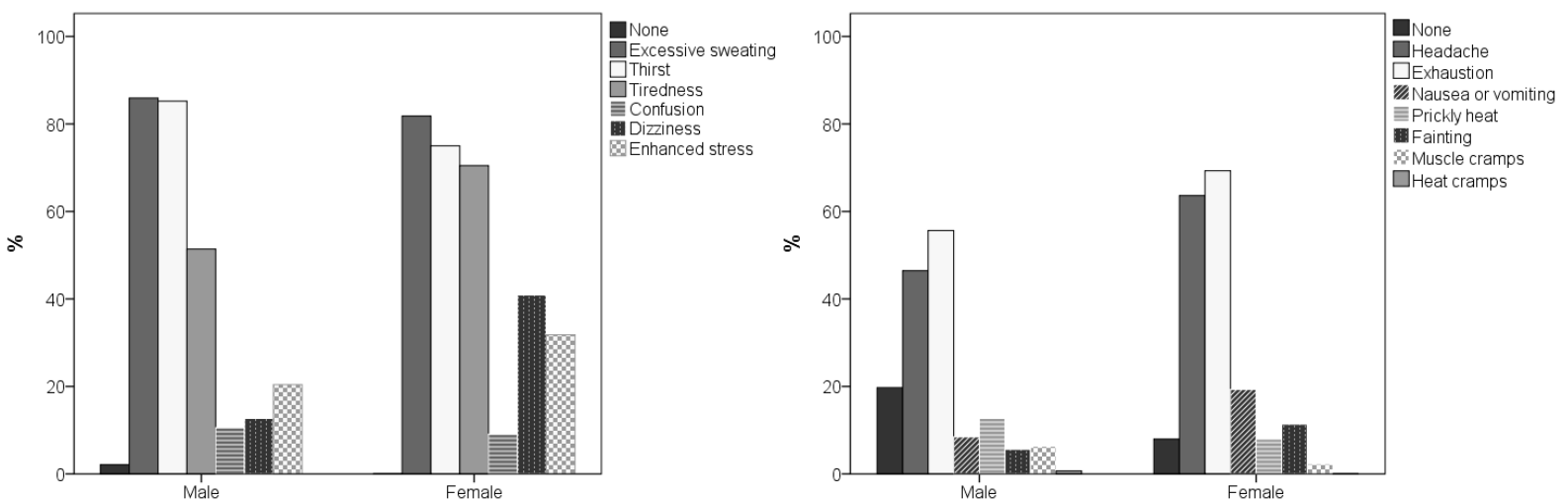

Figure 3: Heat stress symptoms (left) and heat-induced health problems (right), self-reported by farmers

Slika 3: Simptomi vročinskega stresa (levo) in z vročino izzvane zdravstvene težave (desno), ki jih zaznavajo kmetje

Significant more headaches were reported in age groups from 20 to 30, and from 41 to 60 years old participants, and significantly fewer participants without health problems during heat waves. Those with chronical diseases have in significantly higher share already experienced exhaustion.

Apart from heat waves' impact on well-being, it was also seen the impact on concentration and productivity (Figure 2 left), so it was already expected that farmers need more time to do the same work during the heat wave (Figure 4 left). There are no statistically significant differences in answers of advisers and farmers; but for both groups more than $60 \%$ claim that farmers need somewhat more time to complete tasks and 15 to $20 \%$ that they need substantially more time to complete manual work. Answers do not depend significantly on age or gender but do depend on the time spent outside and on having a chronical disease. These findings agree with the study of Venugopal et al. (2016) among 442 outdoor workers in India, where $57 \%$ reported productivity losses due to heat stress. Cited reasons for productivity losses were: extended work hours due to fatigue/exhaustion, sickness/hospitalization and wages lost. It is worker's natural protection to slow down work or limit working hours, which reduces productivity (UNDP, 2016).
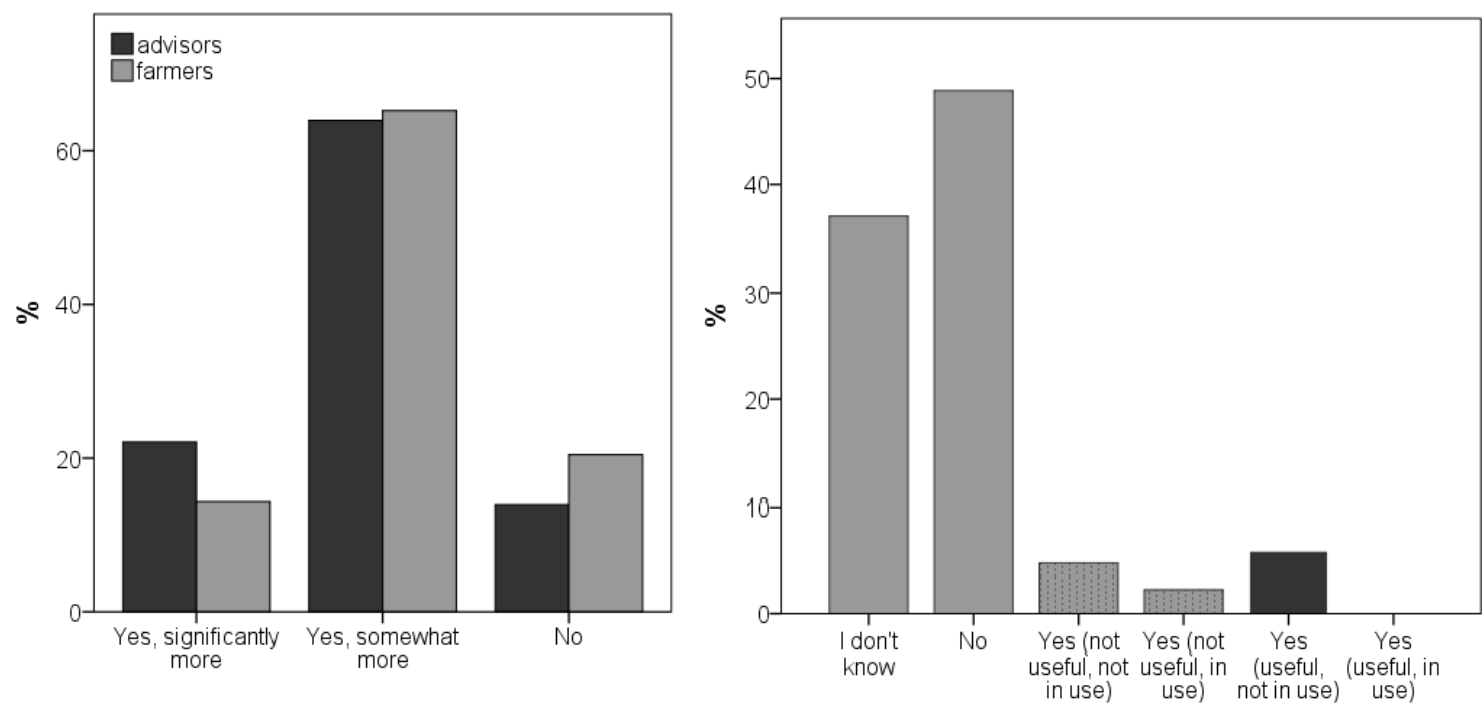

Figure 4: Answers of advisers (black) and farmers (gray) to the question if farmers need more time to do the same work during the heat wave (left), and answers of advisers to the question if there are regulations or guidelines what to do during heat waves (right)

Slika 4: Odgovori kmetijskih svetovalcev (črno) in kmetov (sivo) na vprašanje, ali kmetje v času vročinskih valov potrebujejo več časa za isto opravilo (levo), in odgovori kmetijskih svetovalcev na vprašanje, ali obstajajo pravila ali usmeritve za delo v času vročinskih valov (desno) 
Even though there are many problems occurring due to heat stress, $61 \%$ of farmers responded that they have never been informed about heat stress impacts and $29 \%$ of advisers that they have never informed farmers about possible impacts. The highest share of farmers has got some information through conversation with advisers $(20 \%)$ and at work safety course $(12 \%)$, also the highest share of advisers (62\%) has responded that they have provided the information through conversation or farmers have got it at the course $(21 \%)$. There have also been used some other means of informing like notifications at info points $(7 \%$ of farmers, $9 \%$ of advisers), brochures ( $7 \%$ of farmers, $6 \%$ of advisers), and messages before heat waves (6\% of farmers, $12 \%$ of advisers). In Australia, almost half of respondents have received heat stress information at a heat-related training $(50 \%)$ and by learning at the workplace (49\%), almost a quarter through information from friends and families (22\%), colleagues ( $22 \%)$, some of them from TV and radio (16\%), SafeWork agency $(15 \%)$, the internet $(8 \%)$, and newspapers $(6 \%)$; only $10 \%$ of respondents stated that they could not access any information about heat stress prevention (Xiang et al., 2016).

It is obvious from Figure 4 (right) that there are no formal regulations or guidelines with instructions which could advisers propose to farmers $(50 \%)$ or advisers do not know about them (37\%). However, $10 \%$ of advisers stated that there are guidelines but not useful (6\% - farmers do not use them, $4 \%$ - farmers use them), and $6 \%$ that there are useful guidelines but farmers do not use them due to a financial aspect or other reason. Not one of the advisers chose the option that there are useful guidelines and farmers follow them. In an Australian survey (Xiang et al., 2016), $51 \%$ of respondents stated that there were guidelines for heat stress prevention during extremely hot weather; however, $56 \%$ of respondents replied that further education/training of workers was needed to reduce the risk of heat stress, and $64 \%$ of respondents agreed that there should be more heat-related regulations and guidelines. Also, Nilsson and Kjellstrom (2010) consider that the adaptive capacity must be developed at all levels including interventions for individual workers such as educational programs to create awareness about heat effects and symptoms, how to reduce risks by taking regular breaks, drinking water, working in shade, and so on.

Although the present and previous investigations indicate that better guidance is warranted, farmers on their own develop procedure that may minimize the impact of heat stress and some advisers recommend methods they consider as effective. The exception is $14 \%$ of advisers that have not yet given farmers any advice and $11 \%$ of farmers that responded they cannot do anything to reduce heat stress (Figure 5). Basic heat prevention measures seem straightforward, commonsense, and simple (e.g., drinking water frequently, wearing light colored and permeable clothes, taking breaks in the shade, and responding to early symptoms) (Xiang et al., 2016).

Accordingly, most farmers (79\%) drink more water, take a break in a cooler space $(54 \%)$ or change to lighter/less clothing (44\%) although only $59 \%, 29 \%$, and $30 \%$ of them have received guidelines from advisers in relation the mentioned procedures. It may be considered that included countermeasures are too low and far from optimal and especially so in relation to the clothing aspect. However, in many occupational settings including agriculture, work overalls or protective clothing is needed for protection from physical, biological and chemical hazards (Gao et al., 2017), and it can cause additional heat stress if it is not meant for hot conditions. Farmers generally try to adjust their working schedule $(73 \%)$ while a lower share take more frequent planned breaks (34\%), but likely have more frequent and longer irregular (unplanned) interruptions of their work (Ioannou et al 2017). These two measures are proposed by similar shares of advisers $(77 \%$ and $41 \%$, respectively). Outdoor workers in Australia report drinking more water $(70 \%)$, wear broad-brimmed hats $(39 \%)$ in similar share to farmers in Slovenia, but less worker report that they reschedule working hours $(34 \%)$ or take a break in a shady area $(33 \%)$. 


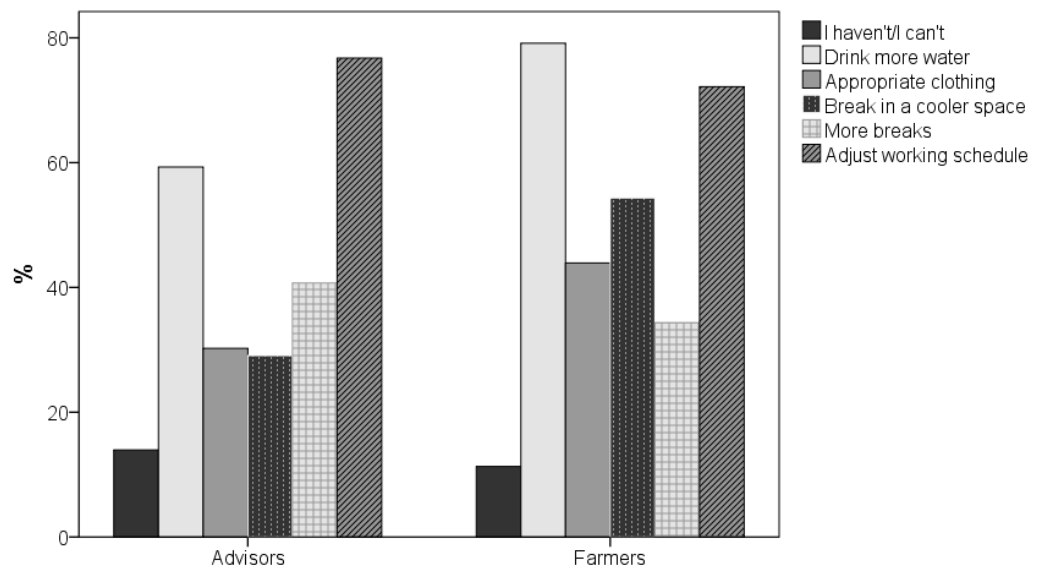

Figure 5: Advisers' instructions for farmers how to reduce heat stress and farmers' actions to reduce heat stress Slika 5: Navodila kmetijskih svetovalcev kmetom, kako naj zmanjšajo vročinski stres, in ukrepi kmetov za zmanjšanje vročinskega stresa

For the present group of farmers in Slovenia some report that it is not possible to reschedule work e.g. complete grass harvesting in morning/evening hours or plan specific tasks to times of the day when the weather/temperature is less adverse as these tasks needs to be completed at given times of the day. E.g. for many farmers the biggest heat issue is experienced during evening milking. The highest fraction of farmers adjusting their working schedule is reported for the coastal region, where it appears that they are more frequently exposed to heat stress. It may also be considered that tradition plays a role as some workers have an incentive to not take rest, as their hourly income will then be higher, and they may risk their health and even their life by not slowing down when their bodies are overheated (UNDP, 2016).

A significant trend for increasing temperatures in Slovenia has been reported over last decades (ARSO,
2014) and further aggravation is forecasted (Morabito et al., 2017). Therefore, it is relevant for farmers and advisers to consider climate changes and the majority (56\% of farmers, $73 \%$ of advisers) responded that farmers lately been exposed to higher levels of heat stress compared to the past, another third (35\% of farmers, $30 \%$ of advisers) agreed with higher exposure, but some attributed this to aging (some of them chose both causes). On the other hand, a quarter of farmers (24\%; and $16 \%$ of advisers) have not noticed higher exposure to heat stress in the last years, attributing it to less demanding manual work tasks as machines have replaced some manual tasks. For comparison, $75 \%$ of Midwestern U.S. advisers consider that climate change aggravate heat exposure for the agricultural sector, although a large part disagree on the human contribution (Mase et al., 2015).

\section{CONCLUSIONS}

This study provides important insights regarding farmers' perceptions and attitudes towards workplace heat stress, and its impacts on well-being, productivity, and concentration. In addition, there it provides an overview of the opinion of agricultural advisers representing an important role for planning and implementing solutions in the agricultural sector in Slovenia. Both workers and advisers consider the impact of heat waves as higher for the agricultural sector compared to other economic sectors, and report immense impact of heat stress on well-being, productivity, and concentration of farmers.

Air temperatures are considered suitable for work outside only for $3 \%$ of farmers, thermal comfort assessment is not dependent on gender, age nor having a chronical disease. Almost all advisers (96\%) confirmed that some kind of problems occur for farmers during heat waves. Thirst, excessive sweating, and tiredness are the most common heat stress symptoms, headaches and exhaustion are the most experienced heat induced health problems and these factors are influenced by gender, age and reported chronical diseases. Almost $80 \%$ of farmers claim that heat has negative effects on their working capacity and more time is required to complete daily duties during heat waves.

There are no official guidelines and the majority of advisers do not guide farmers in relation to implementing solutions to mitigate heat stress. 
Nevertheless, the majority of farmers report that they drink more water and adjust clothing, while a lower fraction report that they try to reschedule work or take breaks in cooler place. Frequent symptoms are experienced and it is our suggestion to research the topic further and work for improved information and implementation of relevant procedures among agricultural and other outdoor workers.

\section{ACKNOWLEDGMENT}

The work was supported by the European Union Horizon 2020 Research and Innovation Action (Project number 668786: Heat Shield). We are indebted to Profs.
Andreas Flouris and Tord Kjellstrom for their assistance.

\section{REFERENCES}

ARSO. (2014). Trendi podnebnih spremenljivk in kazalcev. Retrieved from: http://meteo.arso.gov.si/met/sl/climate/trends/

ARSO. (2016). Sprememba podnebja v Sloveniji do sredine 21. stoletja. Retrieved from: http://meteo.arso.gov.si/uploads/probase/www/clim ate/PSS/scenariji/letak_RCP45_2070.pdf

Flouris, A. D., McGinn, R., Poirier, M. P., Louie, J. C., Ioannou, L. G., Tsoutsoubi, L., Sigal, R. J., Boulay, P., Hardcastle, S. G., Kenny, G. P. (2017). Screening criteria for increased susceptibility to heat stress during work or leisure in hot environments in healthy individuals aged $31-70$ years.

Temperature. doi:10.1080/23328940.2017.1381800

Gao, C., Kuklane, K., Östergren, P. O., Kjellstrom, T. (2017). Occupational heat stress assessment and protective strategies in the context of climate change. International Journal of Biometeorology. doi:10.1007/s00484-017-1352-y

Hübler, M., Klepper, G., Peterson, S. (2008). Costs of climate change: The effects of rising temperatures on health and productivity in Germany. Ecological Economics, 68, 381-393. doi:10.1016/j.ecolecon.2008.04.010

Ioannou, L. G., Tsoutsoubi, L., Samoutis, G., Kajfez Bogataj, L., Kenny, G.P., Nybo, L., Kjellstrom, T., Flouris, A. D. (2017). Time-motion analysis as a novel approach for evaluating the impact of environmental heat exposure on labor loss in agriculture workers. Temperature, 4 (3), 330-340. doi:10.1080/23328940.2017.1338210

Kjellstrom, T., Odland, J. O., Nilsson, M. (2011). Progress in the Hothaps program assessing impacts and prevention of heat effects on working people in relation to local climate change. Asia Pacific Newslett Occup Heal Saf, 18, 24-5.
Li, X., Chow, K. H., Zhu, Y., Lin, Y. (2016). Evaluating the impacts of high-temperature outdoor working environments on construction labor productivity in China: A case study of rebar workers. Building and Environment, $\quad 95, \quad 42-52$. doi:10.1016/j.buildenv.2015.09.005

Lucas, R. A. I., Epstein, Y., Kjellstrom, T. (2014). Excessive occupational heat exposure: a significant ergonomic challenge and health risk for current and future workers. Extreme Physiology and Medicine, 3: 14. doi:10.1186/2046-7648-3-14

Lumingu, H. M. M., Dessureault, P. (2009). Physiological responses to heat strain: A study on personal monitoring for young workers. Journal of Thermal Biology, 34, 299-305. doi:10.1016/j.jtherbio.2009.04.001

Mase, A. S., Cho, H., Prokopy, L. S. (2015). Enhancing the Social Amplification of Risk Framework (SARF) by exploring trust, the availability heuristic, and agricultural advisers' belief in climate change. Journal of Environmental Psychology, 41, 166-176. doi:10.1016/j.jenvp.2014.12.004

Morabito, M., Crisci, A., Messeri, A., Messeri, G., Betti, G., Orlandini, S., Raschi, A., Maracchi, G. (2017). Increasing Heatwave Hazards in the Southeastern European Union Capitals. Atmosphere, 8(7), 115. doi:10.3390/atmos8070115

Nilsson, M. \& Kjellstrom, T. (2010). Climate change impacts on working people: how to develop prevention policies. Global Health Action, 3, 5774. doi:10.3402/gha.v3i0.5774

Nybo, L., Kjellstrom, T., Flouris, A. D., Kajfež Bogataj, L. (2017). Global heating: Attention is not enough; we need acute and appropriate actions. $\begin{array}{llll}\text { Temperature. } & 4 & \text { (3), } & \text { 199-201. }\end{array}$ doi:10.1080/23328940.2017.1338930

Spector, J. T. \& Sheffield, P. E. (2014). Re-evaluating Occupational Heat Stress in a Changing Climate. 
The Annals of Occupational Hygiene, 58, 8, 936942. doi:10.1093/annhyg/meu073

UNDP. (2016). Climate change and labour: impacts of heat in the workplace. Retrieved from: http://www.undp.org/content/undp/en/home/library page/climate-and-disaster-resilience-/tacklingchallenges-of-climate-change-and-workplace-heatfor-dev.html

Venugopal, V., Chinnadurai, J. S., Lucas, R. A. I., Kjellstrom, T. (2016). Occupational Heat Stress Profiles in Selected Workplaces in India. International Journal of Environmental Research and Public Health, 13, 89. doi:10.3390/ijerph13010089
Xiang, J., Hansen, A., Pisaniello, D., Bi, P. (2016). Workers' perceptions of climate change related extreme heat exposure in South Australia: a crosssectional survey. BMC Public Health, 16, 549. doi:10.1186/s12889-016-3241-4

Zander, K. K., Botzen, W. J. W., Oppermann, E., Kjellstrom, T., Garnett, S. T. (2015). Heat stress causes substantial labour productivity loss in Australia. Nature Climate Change, 5, 647-651. doi:10.1038/nclimate2623

Zhang, K., Arauz, R. F., Chen, T. H., Cooper, S. P. (2016). Heat effects among migrant and seasonal farmworkers: a case study in Colorado, Occupational and Environmental Medicine, 73(5), 324-8. doi:10.1136/oemed-2015-103332 